\title{
Solid-State Emissive BODIPY Dyes with Bulky Substituents As Spacers
}

\author{
Tugba Ozdemir, ${ }^{\dagger}$ Serdar Atilgan, ${ }^{\ddagger} \S$ Ilker Kutuk, ${ }^{\ddagger}$ Leyla T. Yildirim," \\ Abdullah Tulek, ${ }^{\dagger}$ Mehmet Bayindir, ${ }^{\dagger, \perp}$ and Engin U. Akkaya ${ }^{*,+, \#}$
}

UNAM-Institute of Materials Science and Nanotechnology, Bilkent University, 06800 Ankara, Turkey, Department of Chemistry, Middle East Technical University, 06531 Ankara, Turkey, Department of Chemistry, Suleyman Demirel University, Isparta 32260, Turkey, Department of Engineering Physics, Hacettepe University, Beytepe, 06800, Ankara, Turkey, and Departments of Physics and Chemistry, Bilkent University, 06800 Ankara, Turkey

eua@fen.bilkent.edu.tr

Received March 17, 2009

\section{ABSTRACT}
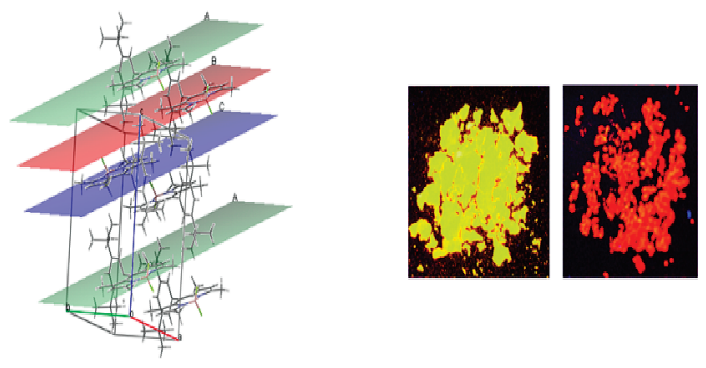

Bright fluorescence of the BODIPY dyes, just like most other fluorophores, is quenched in the solid state due to reabsorption and selfquenching. However, introduction of bulky tert-butyl substituents on the meso-phenyl groups result in more spaced packing in the solid state, resulting in highly luminescent powders and films.

Emissive solids are highly in demand for various applications, including photoelectric conversion ${ }^{1}$ and LED (OLED) ${ }^{2}$ applications. However, organic compounds with emissions in the solid state are rare. This is hardly surprising, because even the brightest emitting fluorophores pack very tightly in the crystalline state or amorphous solid phase (as thin films) leading to very significant quenching. ${ }^{3}$

In addition, strong extinction of both excitation and emission light in the solid phase, especially if the Stokes' shift is small, ${ }^{4}$ should be very detrimental for solid-state

* To whom correspondence should be addressed. Tel: 903122903570. Fax: 903122664068 .

UNAM-Institute of Materials Science and Nanotechnology, Bilkent University.

Department of Chemistry, Middle East Technical University.

$\S$ Department of Chemistry, Suleyman Demirel University.

"Department of Engineering Physics, Hacettepe University.

${ }^{\perp}$ Department of Physics, Bilkent University.

\# Department of Chemistry, Bilkent University. emission. It appeared to us that there may be a relatively easy solution to this problem, even for a fluorophore of high extinction coefficients and small Stokes' shift such as a typical BODIPY dye, namely, the use of orthogonal bulky substituents. A similar strategy was recently suggested by Zhang and co-workers. ${ }^{5}$ Very interesting applications of BODIPY dyes emerged in recent years, ${ }^{6}$ some of them originating from activity in our group. ${ }^{6 e, g}$

(1) (a) Wang, Z.-S.; Li, F.-Y.; Hang, C.-H.; Wang, L.; Wei, M.; Jin, L.-P.; Li, N.-Q. J. Phys. Chem. B. 2000, 104, 9676. (b) Ehret, A.; Stuhl, L.; Spitler, M. T. J. Phys. Chem. B. 2001, 105, 9960. (c) Hara, K.; Sato, T.; Katoh, R.Ü.; Furube, A.; Ohga, Y.; Shinpo, A.; Suga, S.; Sayama, K.; Sugihara, H.; Arakawa, H. J. Phys. Chem. B 2003, 107, 597. (d) Thomas, K. R. J.; Kin, J. T.; Hsu, Y.-C.; Ho, K.-C. Chem. Commun. 2005, 4098. (e) Hagberg, D. P.; Edvinsson, T.; Marinado, T.; Boschloo, G.; Hagfeld, A.; Sun, L. Chem. Commun. 2006, 2245. (f) Li, S.-L.; Jiang, K.-J.; Shao, K.F.; Yang, L.-M. Chem. Commun. 2006, 2792. (g) Zhang, Y.-Q.; Wang, J.-X.; Ji, Z.-Y.; Hu, W.-P.; Jiang, L.; Song, Y.-L.; Zhu, D.-B. J. Mater. Chem. 2007, 17, 90 . 
We now propose that strategic placement of very bulky groups $^{7}$ on the BODIPY core structure should hinder $\pi-\pi$ stacking ${ }^{8}$ of the chromophore, which is likely to be responsible for the quenching of the emission in the solid state for most aromatic fluorophores; tert-butyl groups are very bulky, and especially when introduced as a 3,5-di-tert-butylphenyl substituent, they are very effective in keeping fluorophore $\pi$-systems apart.

With these considerations, we synthesized compounds $\mathbf{1}$ and 2 (Figure 1). The reactions of appropriate aryl aldehydes and the corresponding pyrroles following usual BODIPY synthesis procedures yielded the dyes $\mathbf{1}$ and $\mathbf{2}$ in satisfactory yields. Absorbance and emission spectra in organic solvents were acquired. Both dyes have high quantum yields in organic solvents $\left(\Phi_{\mathrm{F}}=0.83\right.$ and 0.91 respectively, in chloroform).

Suitable crystals for single-crystal X-ray diffraction were obtained by the slow evaporation of $\mathrm{CHCl}_{3}$ solutions at ambient temperature. Crystal structures were as expected,

(2) (a) Tang, C. W.; VansSlyke, S. A. Appl. Phys. Lett. 1987, 51, 913. (b) Tang, C. W.; VansSlyke, S. A.; Chen, C. H. J. Appl. Phys. 1989, 65, 3610. (c) Schi, J.; Tang, C. W. Appl. Phys. Lett. 1997, 70, 1665. (d) Kraft, A.; Grimsdale, A. C.; Holmes, A. B. Angew. Chem. 1998, 110, 416; Angew. Chem., Int. Ed. 1998, 37, 402. (e) Mitschke, U.; Bäuerle, P. J. Mater. Chem. 2000, 10, 1471. (f) Wong, K.-C.; Chien, Y.-Y.; Chen, R.-T.; Wang, C.-F.; Liu, Y.-T.; Chiang, H.-H.; Hsieh, P.-Y.; Wu, C.-C.; Chou, C. H.; Su, Y. O.; Lee, G.-H.; Peng, S.-M. J. Am. Chem. Soc. 2002, 124, 11576. (g) Tonzola, C. J.; Alam, M. M.; Kaminsky, W. K.; Jenekhe, S. A. J. Am. Chem. Soc. 2003, 125, 13548. (h) Yeh, H.-C.; Chan, L.-H.; Wu, W.-C.; Chen, C.-T. J. Mater. Chem. 2004, 14, 1293. (i) Chen, C.-T. Chem. Mater. 2004, 16, 4389. (j) Mizobe, Y.; Tohnai, N.; Miyata, M.; Hasegawa, Y. Chem. Commun. 2005, 1839. (k) Berner, D.; Klein, C.; Nazeeruddin, M. D.; de Angelis, F.; Castellani, M.; Bugnon, P.; Scopelliti, R.; Zuppiroli, L.; Graetzel, M. J. Mater. Chem. 2006, 16, 4468. (1) Ooyama, Y.; Mamura, T.; Yoshida, K. Terahedron Lett. 2007, 48, 5791. (m) Ooyama, Y.; Hayashi, A.; Okamoto, T.; Egawa, H.; Mamura, T.; Yoshida, K. Eur. J. Org. Chem. 2008, 3085.

(3) (a) Ooyama, Y.; Okamoto, T.; Yamaguchi, T.; Suzuki, T.; Hayashi, A.; Yoshida, K. Chem.-Eur. J. 2006, 12, 7827. (b) Ooyama, Y.; Kagawa, Y.; Harima, Y. Eur. J. Org. Chem. 2007, 3613.

(4) Langhals, H.; Krotz, O.; Polborn, K.; Mayer, P. Angew. Chem., Int. Ed. 2005, 44, 2427.

(5) Zhang, D.; Wen, Y.; Xiao, Y.; Yu, G.; Liu, Y.; Qian, X. Chem. Commun. 2008, 4777.

(6) (a) Loudet, A.; Burgess, K. Chem. Rev. 2007, 107, 489. (b) Ziessel, R.; Ulrich, G.; Harriman, A. New J. Chem. 2007, 31, 496. (c) Ulrich, G.; Ziessel, R.; Harriman, A. Angew. Chem., Int. Ed. 2008, 47, 1854. (d) Qi, X.; Jun, E. J.; Xu, L.; Kim, S.-J.; Hong, J. S. J.; Yoon, Y. J.; Yoon, J. J. Org. Chem. 2006, 71, 2881. (e) Atilgan, S.; Ekmekci, Z.; Dogan, A. L.; Guc, D.; Akkaya, E. U. Chem. Commun. 2006, 4398. (f) Ela-Erten, S.; Yilmaz, M. D.; Icli, B.; Dede, Y.; Icli, S.; Akkaya, E. U. Org. Lett. 2008, 10, 3299. (g) Ozlem, S.; Akkaya, E. U. J. Am. Chem. Soc. 2009, 131, 48.

(7) (a) Ooyama, Y.; Ishii, A.; Kagawa, Y.; Imae, I.; Harima, Y. New J. Chem. 2007, 31, 2076. (b) Davis, R.; Abraham, S.; Rath, N. P.; Das, S. New J. Chem. 2004, 28, 1368. (c) Horiguchi, E.; Matsumoto, S.; Funabiki, K.; Matsui, M. Bull. Chem. Soc. Jpn. 2005, 78, 1167. (d) Chiang, C.-L.; Wu, M.-F.; Dai, D.-C.; Wen, Y.-S.; Wang, J.-K.; Chen, C.-T. Adv. Funct. Mater. 2005, 15, 231. (e) Ooyama, Y.; Nakamura, T.; Yoshida, K. New J. Chem. 2005, 29, 447. (f) Ooyama, Y.; Yoshikawa, S.; Watanabe, S.; Yoshida, K. Org. Biomol. Chem. 2007, 5, 1260.

(8) (a) de Halleux, V.; Calbert, J.-P.; Brocorens, P.; Cornil, J.; Declercq, J.-P.; Brédas, J.-L.; Geerts, Y. Adv. Funct. Mater. 2004, 14, 649. (b) Yeh, H.-C.; Wu, W.-C.; Wen, Y.-S.; Dai, D.-C.; Wang, J.-K.; Chen, C.-T. J. Org. Chem. 2004, 69, 6455. (c) Mizukami, S.; Houjou, H.; Sugaya, K.; Koyama, E.; Tokuhisa, H.; Sasaki, T.; Kanesato, M. Chem. Mater. 2005, 17, 50. (d) Yoshida, K.; Yamazaki, J.; Tagashira, Y.; Watanabe, S. Chem. Lett. 1996, 9. (e) Yoshida, K.; Tachikawa, T.; Yamasaki, J.; Watanabe, S.; Tokita, S. Chem. Lett. 1996, 1027. (f) Yoshida, K.; Miyazaki, H.; Miura, Y.; Ooyama, Y.; Watanabe, S. Chem. Lett. 1999, 837. (j) Yoshida, K.; Ooyama, Y.; Tanikawa, S.; Watanabe, S. Chem. Lett. 2000, 714. (k) Yoshida, K.; Ooyama, Y.; Tanikawa, S.; Watanabe, S. J. Chem. Soc., Perkin Trans. 2 2002, 708. (1) Ooyama, Y.; Yoshida, K. New J. Chem. 2005, 29, 1204. (m) Langhals, H.; Potrawa, T.; Nöth, H.; Linti, G. Angew. Chem. 1989, 101, 497.

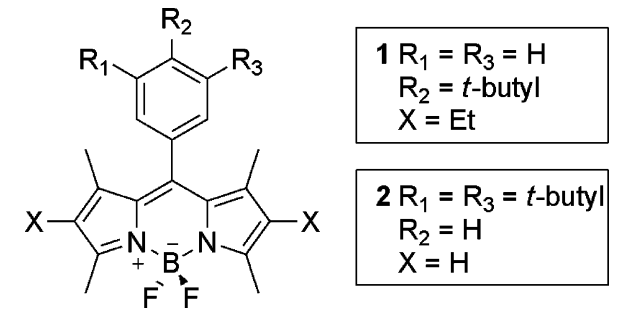

Figure 1. Structure of compounds $\mathbf{1}$ and 2.

with nearly orthogonal (dihedral angles of $79.6^{\circ}$ and $84.3^{\circ}$ for $\mathbf{1}$ and 2, respectively) 8-phenyl substituents (Figure 2).

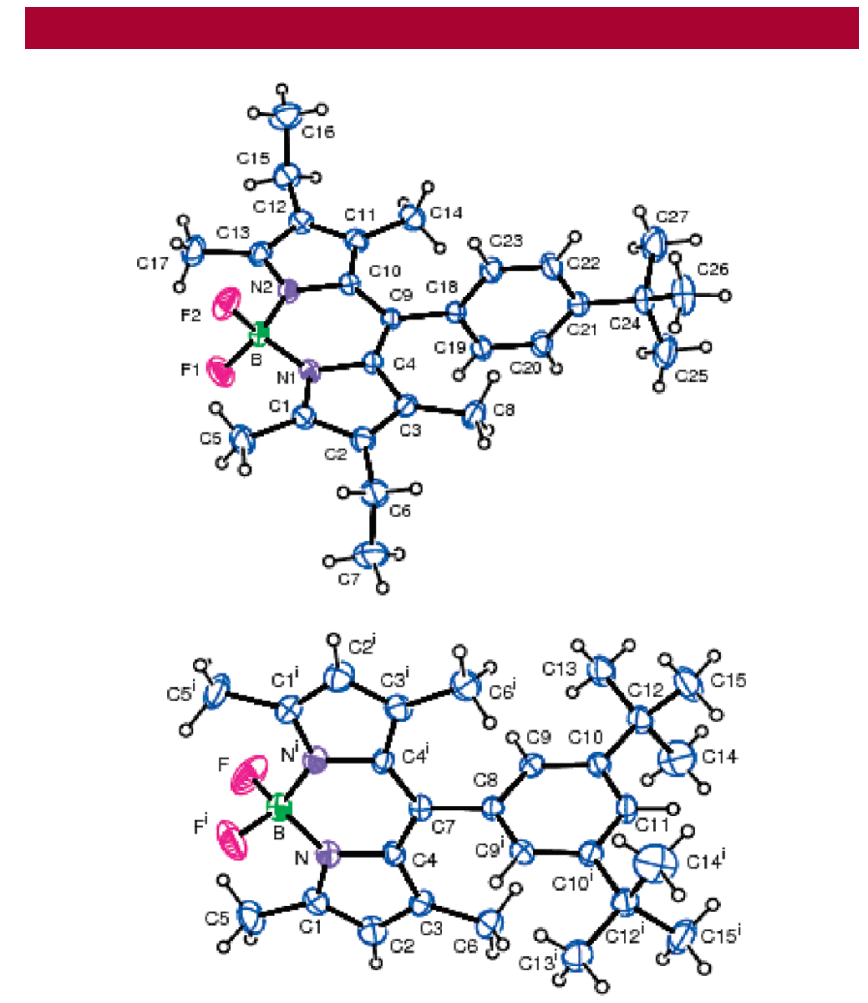

Figure 2. ORTEP drawings of compounds $\mathbf{1}$ (top) and $\mathbf{2}$ (bottom).

With a careful study of the unit cell, an interesting observation was made: the distance between the closest overlapping near-parallel $\pi$-surfaces (defined as the boradiazaindacene framework, planes A in neighboring unit cells in Figures 3 and 4) in compound $\mathbf{1}$ was considerably larger (14.3 $\AA$ ) than the similar distance $(10.1 \AA)$ in $\mathbf{2}$. Both of them in turn are much larger compared to a reference BODIPY dye with no meso substituent and available crystallographic structure. ${ }^{9}$ For that compound (see the Supporting Information), the comparable distance is just $3.51 \AA$. Between other planes $(\mathrm{A}-\mathrm{C})$ the overlap is only partial. This clearly indicates that

(9) (a) Bandichhor, R.; Thivierge, C.; Bhuvanesh, N. S. P.; Burgess, K. Acta. Crystallogr., Sect. E 2006, 62, 4310. (b) Wang, D. C.; Wang, H. P.; Gao, S.; Zhang, T. Y.; Peng, X. J. Acta. Crystallogr., Sect. E 2007, 63, 2238. 


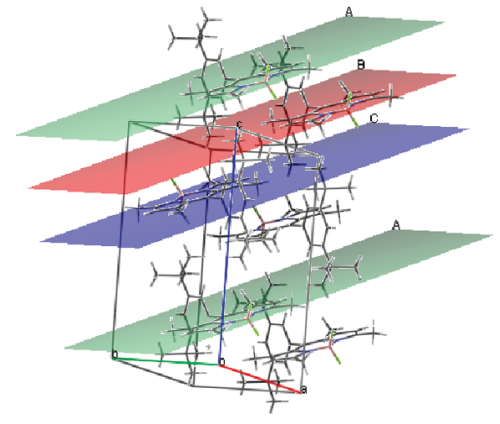

Figure 3. Packing diagram for compound $\mathbf{1}$.

introduction of tert-butyl groups act as a molecular separator, extending the lifetime of the excited states in the solid state. Not suprisingly, while both compounds $\mathbf{1}$ and $\mathbf{2}$ are luminescent in the solid state, many other BODIPY dyes are not.

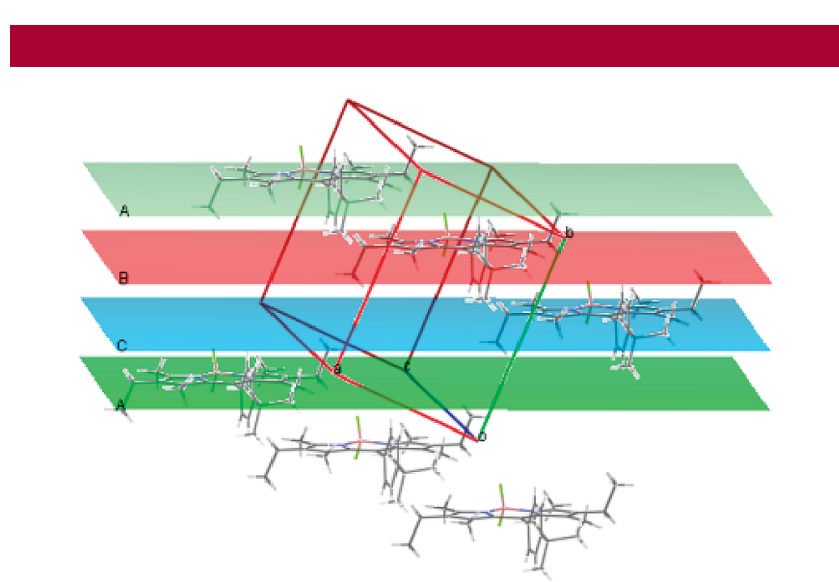

Figure 4. Packing diagram for compound 2.

Encouraged by the bright luminescence of compounds $\mathbf{1}$ and $\mathbf{2}$ in the powder form, thin films of these two dyes were prepared for the determination of emission spectra in the solid state. Dye films were prepared by drop casting the solution with toluene as the solvent, on to the glass substrate, and waiting until the solution dries. Concentrations of the solutions were 10.0 and $36.0 \mathrm{mg} / \mathrm{mL}$ for dye $\mathbf{1}$ and $\mathbf{2}$, respectively. A subsequent postbaking process was performed under rough vacuum conditions at $80{ }^{\circ} \mathrm{C}$ for $1 \mathrm{~h}$. The final BODIPY film thickness was $300 \mathrm{~nm}$ for dye $\mathbf{1}$ and $250 \mathrm{~nm}$ for dye $\mathbf{2}$ as determined by the use of a surface texture profiler.

Absorption spectra of the dye films (Figure 5, top) were measured by a spectrophotometer, and the photoluminescence was characterized by exciting at $325 \mathrm{~nm}$ using a continuous $\mathrm{He}-\mathrm{Cd}$ laser and acquiring the emission data by a fibercoupled spectrometer. The excited area on the films was

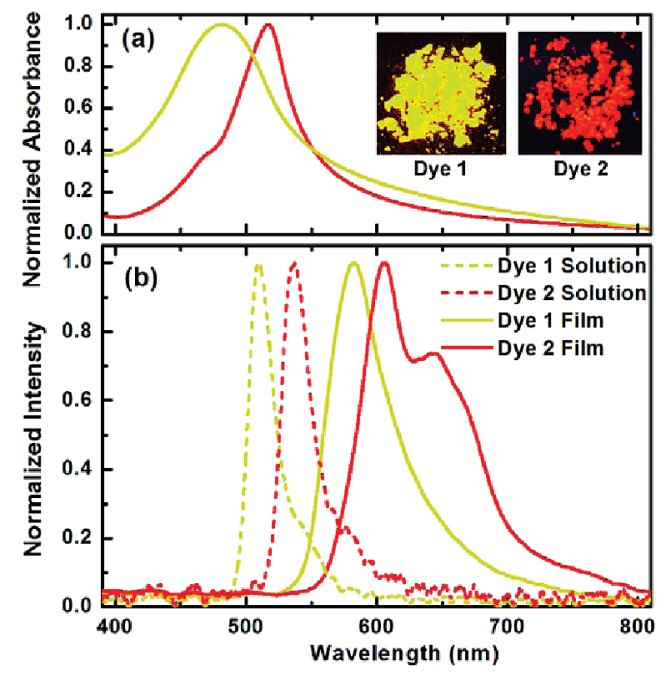

Figure 5. Absorption spectra of the thin films (top) and the emission spectra (bottom) of the dyes $\mathbf{1}$ and $\mathbf{2}$ in solution and as thin films. The inset shows the powder form of the compounds under UV irradiation at $360 \mathrm{~nm}$.

approximately $1 \mathrm{~mm}^{2}$, and the average excitation power was $4 \mathrm{~mW}$. The photoluminescence for the solution phase of the dyes was acquired in the same way as the dye films. The introduction of two ethyl substituents on the 2 and 6 positions of the BODIPY core results in a red shift of approximately $30 \mathrm{~nm}$, and this red shift is apparent also in the solid state. Compared to the solution spectra, there is significant red shift of the peak positions in the solid state, which is to be expected, considering stronger intermolecular interactions. Moreover, another smaller peak for compound $\mathbf{2}$ is clearly present in the spectrum of the dye film obtained using compound 2, which is indicative of the presence aggregate structures in this compound. This is also to be expected, as 3,5-di-tert-butylphenyl groups are clearly superior to 4-tertbutylphenyl groups in keeping the BODIPY units apart.

In conclusion, we demonstrated that simple structural modifications on the BODIPY core can lead to bright emissive compounds in the solid state, and fluorescent thin films can be manufactured without the addition of any polymeric matrix material.

Acknowledgment. We gratefully acknowledge support from the Turkish Academy of Sciences (TUBA) and TUBITAK (Grant Nos. 45 106T348 and 106G090).

Supporting Information Available: Synthesis procedures and additional spectroscopic and crystallographic data. This material is available free of charge via the Internet at http://pubs.acs.org.

OL9005568 